\title{
The Role of Prolactin in the Evolution of Prostate Cancer
}

\author{
Maria Elena Hernandez ${ }^{1}$, Michael J. Wilson ${ }^{2}$ \\ ${ }^{1}$ Centro de Investigaciones Cerebrales and Facultad de Medicina, Universidad Veracruzana, Xalapa, Mexico \\ ${ }^{2}$ Department of Pharmacology and Department of Laboratory Medicine and Pathology, University of Minnesota, \\ VA Medical Center, Minneapolis, USA \\ Email: elenahernandez@uv.mx
}

Received July 21, 2012; revised August 29, 2012; accepted September 21, 2012

\begin{abstract}
Today there is significant information indicating an effect of prolactin on the prostate gland. It has been shown to be involved in mechanisms leading to the synthesis of some proteins such as PSA and cathepsin D, synthesis of citrate and accumulation of zinc. Also, at the behavioral level, prolactin is known to control some aspects of reproduction, including documentation on the physiology of the prostate and the possibility to trigger pathologies in this sex gland. Although the later still is not clear, there is a correlation between the level of prolactin and the presence of prostate pathologies. Thus, the aim of this review is to show how prolactin is involved in the progression of some pathologies of this male sexual gland.
\end{abstract}

Keywords: Second Messengers; Prolactin Receptor; Androgens; Hyperprolactinemia

\section{Introduction}

Prolactin (PRL) is a protein hormone that in vertebrates regulates several functions, including those related to glands involved in reproduction, such as the prostate. In the latter, PRL controls the zinc uptake, citrate synthesis, and the expression of both androgen receptor and cathepsin D. PRL also triggers pathologies in the prostate by still unknown mechanisms. Notwithstanding the controversy of whether it acts alone or in concert with androgens, what is certain is that the serum elevation of PRL has a significant relationship with the presence of hyperplasia or cancer of the prostate. However, to date there is a poor interest on the issue since most of the information suggests that androgens are the main hormone triggering prostate cancer. Thus, this paper is focused to show that PRL, alone or in combination with androgens, may also be responsible for promoting the development of the disease.

\section{Prolactin in the Development and Physiology of the Prostate Gland}

PRL is a peptide hormone with a sequence of 199 aminoacids in humans and 197 in rats, with sequence similarities to those of growth hormone $(\mathrm{GH})$ and placental lactogen (PL). These three hormones share geometric, structural and biological characteristics; hence, they belong to the same family of proteins PRL/GH/PL [1]. Prl has a molecular weight around $23 \mathrm{kDa}$, and is stabilized by three disulfure links in residues of cysteine $\mathrm{Cys}^{4}-\mathrm{Cys}^{11}$,
$\mathrm{Cys}^{58}{ }^{5} \mathrm{Cys}^{174}$, and $\mathrm{Cys}^{191}{ }^{1} \mathrm{Cys}^{199}$, that form three loops giving a particular shape to the molecule [2] Figure 1. PRL is synthesized mainly in lactotroph cells (or mammotroph) in the adenohypophysis [3], and also by cells of the mammary gland, uterus, and placenta [1]. Interestingly PRL has also been reported present in the epithelial cells of the prostate gland, suggesting a local impact on the functioning of these cells [4]. It is also known that in synergy with androgens, PRL controls the growth and development of the prostate [5]. During normal development PRL triggers duct morphogenesis, and in adults, even in the absence of androgens, it induces the primary growth of the stroma, a process also observed in transgenic mice with over expression of PRL [6]. On the other hand, in rats it has been reported that PRL, along with androgens, stimulates the development and secretory activity of the prostate lobules, with the dorsal and lateral regions most influenced by this synergism [7].

In adults, the main function of the prostate is to produce prostatic secretions, transferred to the urethra in response to sexual stimulation for formation of the semen. The content of this fluid is diverse, but only a few components are under the control of PRL. Thus, it is known that PRL stimulates the synthesis and/or accumulation of citrate and zinc, and activation of Bcl-2 (antiapoptotic protein) [8-14]. Also, it is reported that PRL stimulates synthesis of certain proteins in a tissue-specific way; e.g., prostatein in the ventral prostate, probasin and the secretory protein of the seminal vesicle (SVS-II or RWB) in the dorsolateral prostate. Although little is known about 


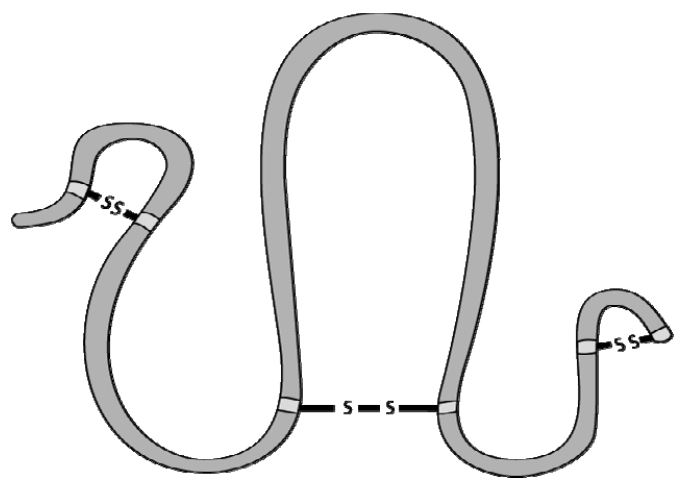

Figure 1. Prolactin is a hormone secreted by the anterior lobe of pituitary. In humans it is conformed for 199 aminoacids with three disulfide bonds $\left(\mathrm{Cys}^{4}-\mathrm{Cys}^{11}, \mathrm{Cys}^{58}-\mathrm{Cys}^{174}\right.$, and $\left.\mathrm{Cys}^{191}-\mathrm{Cys}^{199}\right)$. Also this protein is produced by the mammary gland, uterus, and placenta.

the function of these proteins, a relationship has been observed between prostatein and mammary and prostatic adenocarcinomas, and RWB with the sexual maturation of the gland $[13,15]$.

The prostate is an accessory sexual gland participating in reproductive processes. It is known that following sexual stimulation, there is an increase in the expression levels of Cathepsin D, an enzyme synthetized by the prostatic epithelial cells and integrated into the prostatic secretion. The contact of a male with a female stimulates the production of this enzyme, but the production is greater if it is a non-contact stimulation [16]. Also in the prostate, sexual stimulation triggers the increase of receptors for PRL and steroid hormones, specifically increasing in expression of androgen receptors [17], the long receptor to PRL [18], and the signal pathways of STAT [19]. Although the relationship among these responding molecules is still unknown and the cell responses they evoke, it is clear that a sexual stimulus is highly specific to promote the synthesis and release of secretory components of the prostate needed for the semen to ensure survival of sperm, and in consequence, ovum fertilization. Although there are few studies incurporating the effects of sexual stimulation, reducing the number of PRL receptors does not affect the execution of sexual behavior [20], but does alter fertility. Up to $20 \%$ of subjects were able to induce pregnancy but can become completely infertile with a longer time [5]. However, this is a topic that deserves further research.

\section{Evidence of the Role of PRL in the Development of Prostate Cancer}

PRL is a hormone that participates in several functions in vertebrates, one of them being the regulation of cell proliferation. Therefore, many studies have focused on evaluation of its role in the different pathologies that are found in the prostate. An important feature of this gland in men is a continuous growth throughout the life of the subject. It has a slow and constant growth starting at the age of 21 up to the age of 40 . Then, there is a second growth period triggered and the gland doubles its weight, from 20 to $40 \mathrm{~g}$, when the subject is around 80 years old. However, in some situations of unknown etiology, this growth is accelerated with the gland reaching a size and weight above these normal levels; i.e., a weight of 50 to $80 \mathrm{~g}$ among men 40 and 50 years old, with different problems associated with a prostate of this size. One of them is benign prostatic hyperplasia (BPH; an enlargement produced by an increase in the number of cells) and the other is a more aggressive phase, such as cancer. It is largely unknown why and what is triggering this modification, but it is known that PRL and testosterone, along or together, seem to do something in the process [21-23]. It has been observed that some human subjects with prostate pathologies have also a higher serum level of PRL [24]. Although it is unknown whether PRL causes the disease or the disease causes PRL increase, what is known is that after inducing an increase in serum PRL, the possibility of prostate pathology is significantly increased [25]. Hence, PRL is now considered as a risk factor in the etiology of prostate pathologies [26].

The idea is that PRL has something to do with prostate pathologies was first demonstrated in several studies with rodents. However, a conclusive demonstration has not been easy to demonstrate due to experimental protocols in use, as well as the possible role of androgens. In spite of this, and with recent evidence, it has been found that PRL can promote prostate cell growth $[27,28]$ by activating a mechanism dealing with the inhibition of apoptosis. In the $\mathrm{LNCaP}$ cell line, as an example, this process was observed when androgens were present $[9,29]$. Also, it has been demonstrated that in synergy with androgens, PRL can promote cell survival and differentiation, and in the absence of androgens it increases the expression of the short and long PRL receptors, and activates the pathways of STAT and MAPK $[4,30]$. Prolactin has also been proposed to induce nodular hyperplasia $[31,32]$ and dysplasia [13].

Studies from transgenic mice with an over expression of the prostate PRL gene [31] and in ArKo mice (without aromatase expression; [33], a dramatic enlargement of the prostate associated with a decrease in the rate of apoptosis and no disease was reported. The same effect was shown in prostate cell cultures from the rat and human $[30,34]$. Thus, it has been proposed that a pathway that seems to be independent from androgen actions evokes PRL effects.

As can be appreciated, evaluation of PRL effects is not an easy task because some pathologies require the presence of androgens, whereas others can be triggered just in the presence of PRL. The questions raised are Why? 
and How? Although the answers are unknown, they could be analyzed by the number and type of genes that become activated by PRL to induce pathology, such as in intraepithelial neoplasia [35]. However, there still is a long way to go in order to decipher the mechanisms activated by PRL that modify prostate morphogenesis.

\section{Normal Pathways for PRL Signal Transduction}

The pleiotropic function induced by PRL in different tissues, including the prostate, starts with the link to a specific membrane receptor, the prolactin receptor (PRLR). It has been identified as a glucoprotein in several tissues and species, and belongs to a superfamily of receptors of the cytokine 1 type [5,36-38]. There is diversity in the isoforms of the receptor as a result of alternative splicing of the RNA synthesized from a single gene. The resulting receptors are different in length and composition of their intracellular domain (DIC), but they are similar in their extracellular (DEC) and transmembranal domains (DTM). In this sense, in humans 4 isoforms are described, a long one (L), a intermediate (I), and two short (S1a and S1b); in the rat there are 3 isoforms, the L with 591 aa, I with 393 aa, and S with 291 aa; and in mice there are also 4 isoforms, the L (589 aa), and three S (S1 with 291 aa, S2 with 284 aa; and S3 with 273 aa) $[2,39,40]$ Figure 2.

The complex PRL-receptor (PRLR) can activate different pathways of intracellular signaling [41], including Stat (signal transducers and activators of transcription proteins). This group of proteins has 5 isoforms known as Stat 1, Stat3, STAT5a and b, and Stat6 Figure 3. The activation of each subunit is different depending on the physiological stimulus. During sexual behavior it was demonstrated that such stimulus induces modifications in the level of activation of Stat 1 and 3 in the prostate. The level of activation of these 2 isoforms is increased with a second consecutive ejaculation in rats, and response of Stat3 was greater than Stat 1. Also, translocation of Stat3 protein to the nucleus was demonstrated, suggesting its role in the regulation of genes probably related to the synthesis of Cathepsin D [16,18], increased during sexual behavior, and probably with regulation of those genes related to cell proliferation.

The other groups of signal pathways used by PRL are the mitogen-activated protein kinases (MAPK), also known as ERK $[42,43]$. MAPK was the first group identified from all signal proteins, and is constituted of two proteins with molecular weights of 44 and $42 \mathrm{kDa}$. The two phosphoacceptor groups of Tyrosine and Threonine, once phosphorylated, activate the MAPK $[44,45]$. However, both proteins have different functions, while ERK2 participates in cell proliferation, ERK1 regulates ERK2 negatively [46]. This signal pathway has a main function in cell proliferation, but in the prostate it also regulates survival, growth and apoptosis [47]. Although there are several studies of ERK1/ERK2 in the prostate, to date it is still unknown how they are related to the physiology

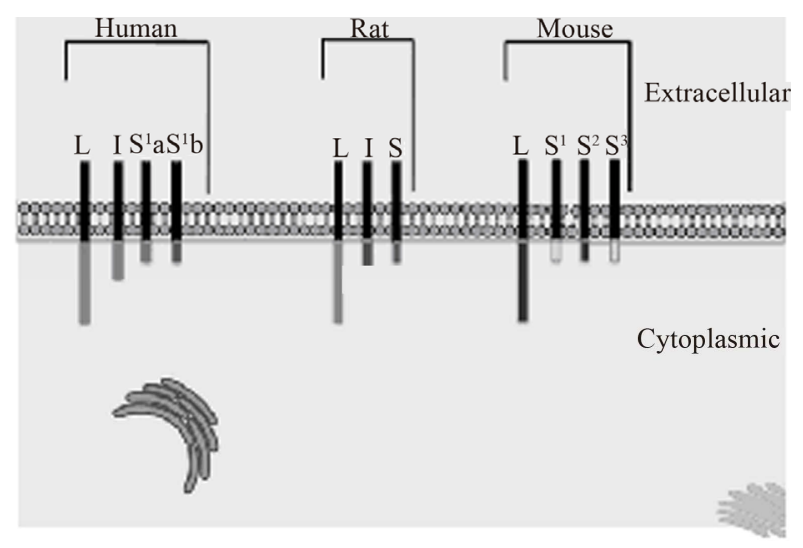

Figure 2. Different PRL receptor isoforms present in human, rat and mouse. There have been reported four isoforms in human; one long (L) one intermediate (I), and two short (S1a and S2b). In rats, three isoforms: one long (L), one intermediate (I), and one short (S). In mice, four: one long (L) and three short (S1, S2, S3). All receptors remain similar in their extracellular domain, the difference is in the cytoplasmic domains of their longuitudes.

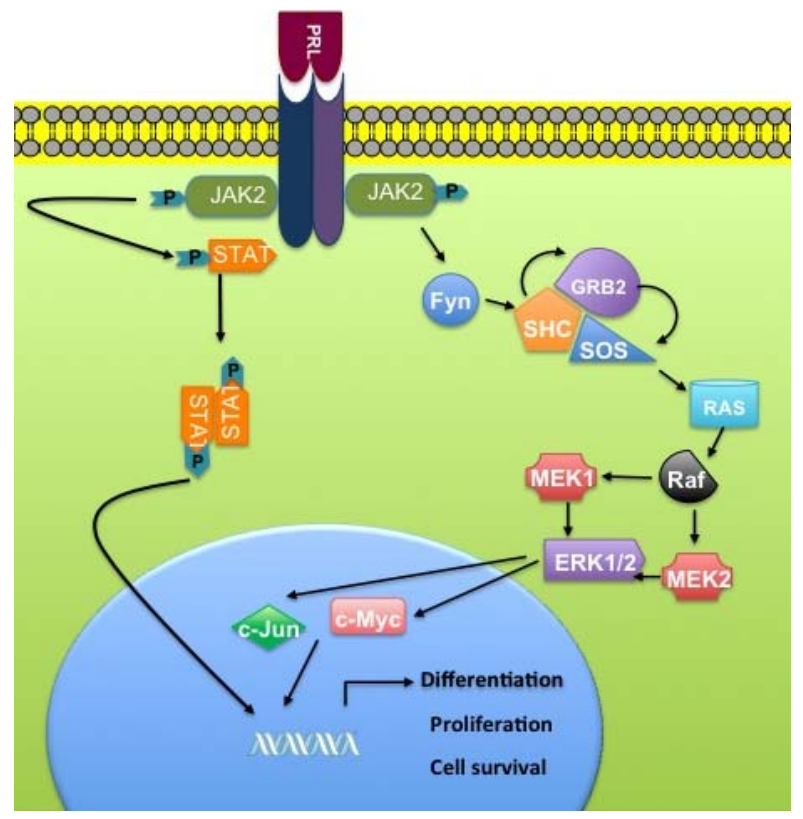

Figure 3. Major signaling pathways of PRLr activation. After the union of PRL to its dimerized receptor, the PRLr activates JAK proteins, these in turn phosphorylate STAT that in consequence is dimerized and translocated to the nucleus. The phosphorilated JAK2 can also activate the MAPK signaling way throught of Fyn, SHC, GRB2 and SOS molecules. The result of these two pathways is the activation of some transcription factors (like c-Jun and c-Myc) that promoute the expression of proliferation, differentation and cell survival genes. 
of the gland and their role when the gland is activated by PRL. However, some studies from cell lines derived from prostate cancer have shown that ERK regulates proliferation, growth and cell survival when it is activated by growth factors or even androgens [47]. On the contrary, it was shown that PRL is unable to activate this pathway when it is added to organ culture [8].

Another group of signal pathways used by PRL to induce effects on prostate epithelial cells is the JNK/SAPK [48]. These kinases have a molecular weight of $54 \mathrm{kDa}$ [44], which, similar to the ERK 1 and 2, requires the phosphorylation at Threonine and Tyrosine sites to become activated. They respond to several stimuli such as UV light, X-rays, hydrogen peroxide, and some hormones including interleukine $1-\beta(1 \mathrm{~L}-1 \beta)$, growth factors, and PRL $[45,49]$. These kinases participate in different functions such as proliferation, oncogenetic transformation, differentiation, inflammation, development, and apoptosis [50]. However, in the specific case of prostate cells, it was observed that following activation of this pathway by PRL, growth could be the result of inhibition of cell apoptosis, with few effects on cell proliferation. This suggests that PRL promotes the survival of PC3 and DU145 cells, instead of promoting cell proliferation when this signal pathway is activated [51]. There is sufficient information showing that these signal pathways become active during prostate pathologies, although there are few studies making a correlation of these pathways with PRL effects. Hence, to date it is still unknown which proteins and genes are activated for the induction of prostate pathologies by PRL, neither is it known what occurs in subjects with sexual experience.

\section{Alterations in PRL Signal Transduction to Induce Progression of Prostate Cancer}

Now it is clear that PRL regulates the prostate by promoting the synthesis of semen components, and influences the expression of some genes by itself or along with androgens. However, its function seems to be dual because it also can modify the prostate in its physiology and morphology in such a way that leads to several kinds of disease states [9,52]. The mechanisms to trigger those events can be diverse, but briefly they can be summed in three steps: the first includes the elevation of systemic levels of PRL, the second is in relation to a higher density of its receptors, and the third is related to the alteration in the signal pathways activated following PRL stimulation. The sum of all of them will finally generate prostate pathologies.

In humans, hyperprolactinemia (HyperPRL) caused by a prolactinoma or any other disorder in the hypophyseal system, is one of the most frequent pituitary clinical diseases. In the short term, the frequent effects of hyperPRL in males are infertility, low sexual desire, and sexual impotence; while in the long term it can generate prostate diseases. Although the latter effect is not conclusive at all, there is a high correlation between HyperPRL and prostate diseases [53]. No matter that controversy exist whether PRL triggers prostate diseases, a fact is that this sex gland has receptors for this hormone that promote proliferation once activated by PRL [54]. What are the mechanisms to trigger those effects? To date they are not known, but it has been shown that one of them includes receptor modulation, that is, the receptor affinity changes as a consequence of the increase in PRL levels [55]. Such change is due to the modification of the lipidic flux, which makes the receptor to be oriented in such a way that increases its probability to receive the hormone [56]. Also, another mechanism proposed is a higher expression of a single receptor type [54]. This was also observed in our lab, the expression of the short receptor was increased after short treatments of hyper PRL for 15 days of hyperPRL [57]. Modulating receptor expression is not just a response to serum levels of PRL but also the degree of the disease, that is, an increase in the expression of PRL receptors has been found in dysplastic tissue, but reduced in a more malignant tissue. This suggests that PRL plays an important role in the induction, development and maintenance of the malignant stage and participates in the early neoplasic transformation, but not in more developed stages [42].

In the case of signal pathway variations observed in the expression of different STAT isoforms, the individual forms were dependent on the actual pathology of the prostate. STAT3, for example, was found to increase in the cell line LNCaP [58,59], and also during the transformation process leading to the refractory prostate cancer [60]. Also, STAT3 is continuously active in the epithelium of malignant prostates and this activation has been associated with advanced cancer. In those subjects with metastasis, STAT3 is $67 \%$ more active with a direct correlation with the serum levels of PSA and with the degree of the pathology according with the Gleason scale [61]. On the other hand, in DU145 and PC-3 cells, it was shown that STAT3 promotes cell migration because it induces the formation of lamelipodia as a consequence of the rearrangement of actin and microtubules [62]. Activation of STAT $5 \mathrm{a} / \mathrm{b}$ was observed in the induction of histological changes, and a transcriptional modification in STAT $5 \mathrm{a} / \mathrm{b}$ is necessary in order to promote development of cancer, that is, expression of a truncated form at the amino terminal of this isoform avoids the repressive action of the inhibitory protein PIAS3 (protein inhibitor of activated STAT) and allowing increased cell proliferation [63]. Also, increased activation of the MAP kinase pathway is found in prostate diseases. In prostate tissue samples with hyperplasia, intraepithelial neoplasia or 
undifferentiated tumors, a strong activation of the MAP p38 is observed, but such activation is not observed in those tumors with some differentiation. Likewise it was shown that inhibition of this pathway could slow down proliferation of PC3 cells [47]. Finally, there is also evidence indicating that the PI3/AKT pathway is implicated in pathologies of the prostate, as this pathway is highly active in LNCaP cells from human carcinoma [64]. The question is: how are these pathways related to PRL for triggering prostate diseases? The few data in this regard indicate that PRL can maintain the activation of these proteins in epithelial cells and by this means promote proliferation and survival of cells in the hyperplastic and cancer tissues $[38,47,65]$. In other words, activation by PRL of the STAT $5 \mathrm{a} / \mathrm{b}$ pathway via Janus Kinase-2 promotes development of cell proliferation, because its inhibition makes the cells enter apoptosis [63], and apparently MAPK does not seem to participate in this process [8].

\section{Alterations in Transduction Pathways of PRL. Relationship with the Androgen Receptor}

As far as can be determined, hyperprolactinemia alters prostate morphology and the extent of these effects differ depending on the degree and duration of elevated PRL exposure [66]. The mechanisms for this could include changes at the PRL receptor level and signal pathways, but also they could be related to the androgen receptor.

The prostate is highly dependent on androgens to orchestrate its appropriate functions, and involution of the gland occurs when this steroid is absent. In vitro studies have shown that decrease in the expression of PIAS1 and SRC1 in hormone-refractory tumors alters the transcriptional activity of the AR, suggesting that these cofactors could be involved in the progression of prostate cancer $[67,68]$. Likewise, diverse mutations in the AR could be another mechanism that lead to or maintains the growth of prostate tumors [69]. However, it is also known that the effects could be mediated together with other hormones such as PRL, which is known to be able to alter the morphology of the prostate Figure 4. Thus, regulation of prostate pathologies seems to rely on complex events that include at least both of these hormones.

It was observed that hyperprolactinemia, induced by an implant of hypophyseal tissue, produces an increase in the weight and DNA content of the lateral lobule of the prostate and a higher concentration of AR in the nucleus. Since hyperprolactinemia produces a decrease in the concentration of testosterone in blood $[9,70]$, it was proposed that PRL can promote the growth of this lobule by increasing the density of the nuclear AR and by this

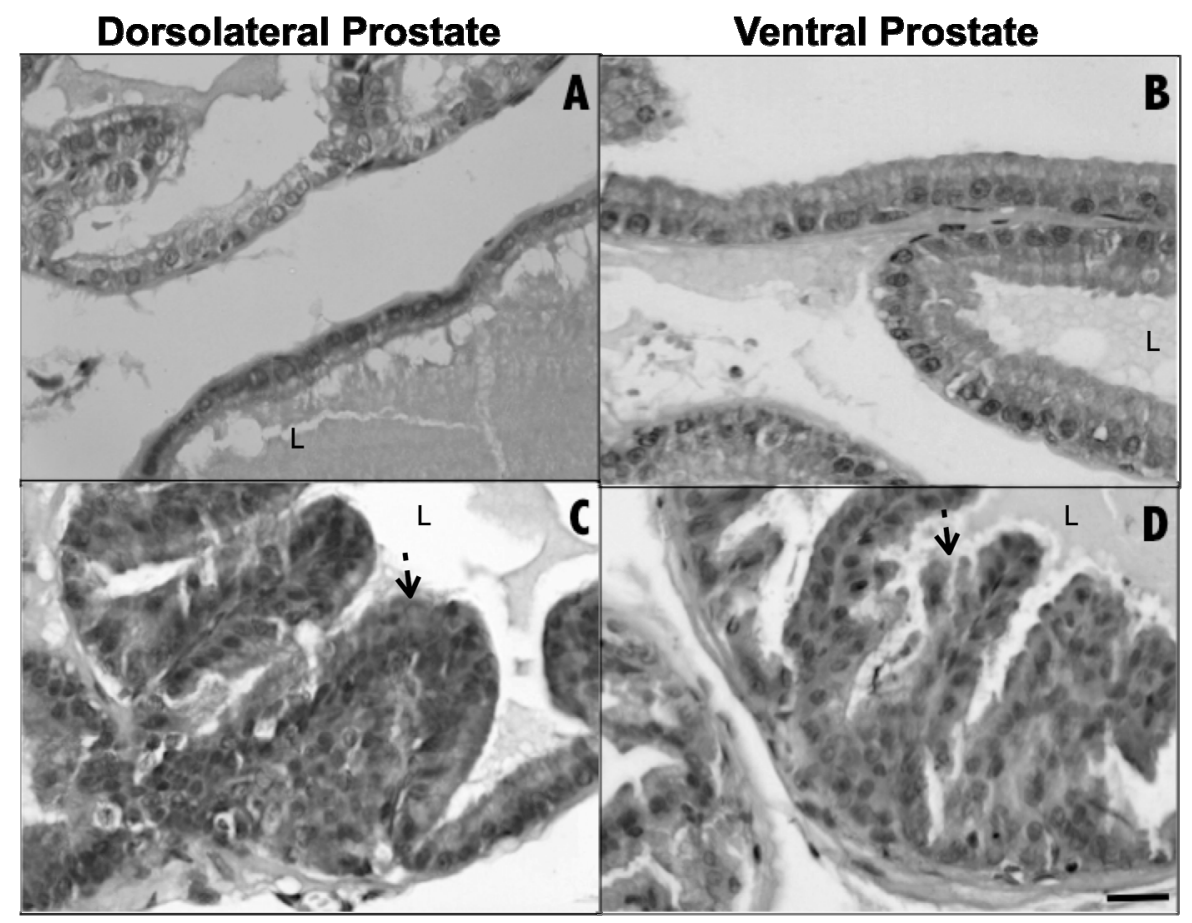

Figure 4. Image of the ventral and dorsolateral prostate tissue. Subjects were treated with prolactin for 3 months. Panel A and $B$ represents normal tissue of the ventral and dorsolateral prostate, showing epithelial cells with typical columnar and cuboidal shape, respectively. Panels $C$ and $D$ represent a ventral and dorsolateral tissue treated with prolactin. Under this condition ephitelial cells completely lose columnar and cuboidal shape, and the cells are invading the lumen as a result of cell proliferation (arrow). $\mathrm{L}=$ lumen, Bar $=\mathbf{5 0} \mu \mathrm{m}$. 
mean optimize the response to circulating androgens [15]. However, the increase of both its protein and its messenger RNA, can be decreased as a consequence of the permanent activation of the Ras-Erk pathway [71]. Also, an increase in AR concentration was observed in hyperprolactinemic subjects that do not show the aromatase enzyme. Under these conditions, an enlargement of the gland was found with some hyperplasic areas [33]. The effects genererted by PRL and AR are not only related to activation of the MAPK pathway but also to that of STAT, which also seems to be implicated. An association between the AR and STAT at the nucleus level was reported and it was proposed that it could be another mechanism for PRL to induce cell proliferation in the prostate $[43,72]$.

The pathological effects of androgens and prolactin also seem to be mediated via activation of the c-myc protein (Figure 3), that has a role in cellular proliferation and apoptosis [73]. In physiological conditions it was reported low levels of this protein but in pathological conditions there is an increase. Thus, in the hyperplasic prostate gland of humans it is found high levels of c-myc, and it also occurs in the intraepithelial neoplasias and cancer, with the effect seen mainly at the nucleus level [74], where a high rate of gene transcription is observed as a consequence of the acetylation increase [75]. On the other hand, it has been reported a stepwise increase of this protein, from the normal tissue to a low and high intraepithelial neoplasia [74]. The increase in the pathological tissue is by activation of the PI3/Akt and MAPK pathways and both of them may act in concert to upregulate the c-myc $[76,77]$. The overexpression of c-myc in prostate cancer also seems to result from a downregulation of a set of microRNAs such as miR-34a [78,79], or because of a decrease in androgen actions through the let-7c microRNA [80]. Furthermore, it has been shown an over expression of c-myc induced by PRL in lymphoma cells through activating the cascade PI3/Akt [48].

In conclusion, to date, the existing information on how PRL can induce prostate pathologies is far from being conclusive. However, what we have observed at this time is that, along with aging of the subject, serum levels of PRL are increased while those of testosterone are decreased, and this hormonal imbalance can be the appropriate means to trigger prostate pathologies, induced mainly by PRL. In other words, the rise of PRL during aging is the key for the presence of prostate pathologies. The question raised is: how does PRL trigger the pathologies? The response is still unknown and neither can it be explained by only the increase in the density of its receptors or by the activation of signal pathways, because the latter are poorly convincing. A second question that we must keep on mind is: is it important to know whether the signal pathways are activated (transient or continuous activation; rapid turnover versus extended binding of PRL by its receptors) or it better expected that prolonged activation of involved pathways leads to activation of additional genes with changes in tissue characteristics and development of pathology? No matter the technological advances and the tools existing today, it is still a difficult issue to deal with these questions, but not impossible. We just require the sum of efforts to understand the generation of this kind of disease.

The mechanisms used by PRL to induce prostate pathologies seem to be quite varied, but the information obtained to date suggests that this hormone can induce prostate pathologies and proliferation via PI3/Akt and MAPK pathways activation, by overexpression of c-myc, as well as by inhibition or activation of some microRNAs such as the miR-341a and let-7c. However, it still remains to analyze how they are related in order to promote cellular migration and also how these proteins affect the cytoskeleton, that is necessary not only to maintain cellular form but also required to maintain the cell attached to the extracellular matrix; questions that are just started to be addressed.

\section{Acknowledgements}

Supported by sabbatical fellowship 159818, CONACyT grant 106531, Department of Veterans Affairs (MW) and program of academic collaboration. We thank the technical assistance of Daisy Herrera and Cynthia Fernandez.

\section{REFERENCES}

[1] A. Bachelot and N. Binart, "Reproductive Role of Prolactin," Reproduction, Vol. 133, No. 2, 2007, pp. 361-369. doi:10.1530/REP-06-0299

[2] N. Ben-Jonathan, C. R. LaPensee and E. W. LaPensee, "What Can We Learn From Rodents about Prolactin in Humans?" Endocrine Review, Vol. 29, No. 1, 2008, pp. 1-41. doi:10.1210/er.2007-0017

[3] J. Neil and G. Nagy, "Prolactin Secretion and Its Control," In: E. Knobil and J. D. Neill, Eds., The Physiology of Reproduction, Raven Press, New York, 1994, pp. 1833-1860.

[4] M. T. Nevalainen, E. M. Valve, P. M. Ingleton, M. Nurmi, P. M. Martikainen and P. L. Harkonen, "Prolactin and Prolactin Receptors Are Expressed in Human Prostate," The Journal of Clinical Investigation, Vol. 99, No. 4, 1997, pp. 618-627. doi:10.1172/JCI119204

[5] C. Boyle-Feysot, V. Goffin, M. Edery, N. Binart and P. Kelly, "Prolactin and Its Receptors: Actions, Signal Transduction Pathways and Phenotypes Observed in PRL Receptor Knockout Mice," Endocrine Review, Vol. 19, No. 3, 1998, pp. 225-2268. doi:10.1210/er.19.3.225

[6] J. Kindblom, K. Dillner, L. Sahlin, F. Robertson, C. Ormandy, J. Törnell and H. Wennbo "Prostate Hyperplasia 
in a Transgenic Mouse with Prostate-Specific Expresion of Prolactin," Endocrinology, Vol. 144, No. 6, 2003, pp. 2269-2278. doi:10.1210/en.2002-0187

[7] C. Nicoll, "Physiological Actions of Prolactin," In: J. Field, H. Magoun and V. Hall, Eds., Handbook of Physiology. A Critical, Comprehensive Presentation of Physiological Knowledge and Concepts, American Physiological Society, 1994, pp. 263-264.

[8] T. J. Ahonen, P. L. Härkönen, H. Rui and M. T. Nevalainen, "PRL Signal Transduction in the Epithelial Compartment of Rat Prostate Maintained as Long-Term Organ Cultures in Vitro," Endocrinology, Vol. 143, No. 1, 2002, pp. 228-238. doi:10.1210/en.143.1.228

[9] F. Van Coppenolle, C. Slomianny, F. Carpentier, B. Le, A. Ahidouch, D. Croix, G. Legrand, F. Dewailly, S. Fornier, H. Caouss, D. Authie, J. Raynaud, C. Beauvillain, P. Dupouy and N. Prevarskaya, "Effects of Hyperprolactinemia on Rat Prostate Growth: Evidence of Androgen-Dependence," American Journal of Physiology Endocrinology and Metabolism, Vol. 280, No. 1, 2001, pp. E120E129.

[10] L. C. Costello, Y. Liu, J. Zou and R. B. Franklin, "Evidence for a Zinc Uptake Transporter in Human Préstate Cancer Cells Which Is Regulated by Prolactin and Testosterone," Journal of Biological Chemestry, Vol. 274, No. 25, 1999, p. 504. doi:10.1074/jbc.274.25.17499

[11] L. C. Costello and R. B. Franklin, "Effect of Prolactin on the Prostate," Prostate, Vol. 24, No. 3, 1994, pp. 162166. doi:10.1002/pros.2990240311

[12] L. C. Costello, L. Lao and R. Franklin, "Citrate Modulation of High-Affinity Aspartate Transport in Prostate Epithelial Cells," Cellular and Molecular Biology, Vol. 39, No. 5, 1993, pp. 515-524.

[13] E. Reiter, B. Hennuy, M. Bruyninx, A. Cornet, M. Klung, M. McNamara, J. Closset and G. Hennen, "Effects of Pituitary Hormones on the Prostate," Prostate, Vol. 38, No. 2, 1999, pp. 159-165. doi:10.1002/(SICI)1097-0045(19990201)38:2<159::AIDPROS10>3.0.CO;2-5

[14] J. Kindblom, "Actions of Prolactin in the Prostate Gland," In: D. Hoseman, Ed., Prolactin, Kluwer Academic Publishers Inc., New York, 2001, pp. 233-245.

[15] G. S. Prins and C. Lee, "Biphasic Response of the Rat Lateral Prostate to Increasing Level of Serum Prolactin," Biology of Reproduction, Vol. 29, No. 4, 1983, pp. 938945. doi:10.1095/biolreprod29.4.938

[16] R. Diaz, "Niveles de Catepsina D Prostática en Respuesta a la Estimulación Sexual en Ratas" Ph.D. Thesis, Universidad Veracruzana, Veracruz, 2006.

[17] M. E. Hernández, A. Soto-Cid, G. E. Aranda-Abreu, R. Díaz, F. Rojas, L. I. Garcia, R. Toledo and J. Manzo, "A Study of the Prostate, Androgens and Sexual Activity of Ale Rats," Reproductive Biology and Endocrinology, Vol. 16, No. 5, 2007, pp. 11-19. doi:10.1186/1477-7827-5-11

[18] M. Silva, "Niveles de mRNA del Receptor a Prolactina en la Próstata Durante la Conducta Sexual de la Rata," Ph.D. Thesis, Universidad Veracruzana, Veracruz, 2009.

[19] A. Soto-Cid, C. R. Hernandez-Kelly, M. E. Hernandez, J.
Manzo, E. González-Mejia, R. C. Zepeda and A. Ortega, "Signal Transducers and Activators of Transcription 1 and 3 in Prostate: Effect of Sexual Activity," Life Sciences, Vol. 79, No. 9, 2006, pp. 919-924. doi:10.1016/j.1fs.2006.03.011

[20] N. Binart, N. Melaine, C. Pineau, H. Kercret, A. M. Touzalin, P. Imbert-Bolloré, P. A. Kelly and B. Jégou, "Male Reproductive Function Is Not Affected in Prolactin Receptor-Deficient Mice," Endocrinology, Vol. 144, No. 9, 2003, pp. 3779-3782. doi:10.1210/en.2003-0409

[21] S. Odoma, G. D. Chisholm, K. Nicol and F. K. Habib, "Evidence for the Association between Blood Prolactin and Androgen Receptors in BPH," Journal of Urology, Vol. 133, No. 4, 1985, pp. 717-720.

[22] J. Meng, C. H. Tsai-Morris and M. L. Dufau, "Human Prolactin Receptor Variants in Breast Cancer: Low Ratio of Short Forms to the Long-Form Human Prolactin Receptor Associated with Mammary Carcinoma," Cancer Research, Vol. 64, No. 16, 2004, pp. 5677-5682. doi:10.1158/0008-5472.CAN-04-1019

[23] S. K. Peirce and W. Y. Chen, "Quantification of Prolactin Receptor mRNA in Multiple Human Tissues and Cancer Cell Lines by Real Time RT-PCR," Journal of Endocrinology, Vol. 171, No. 1, 2001, pp. R1-R4. doi:10.1677/joe.0.171R001

[24] P. Lissoni, M. Mandala, F. Ropvelli, M. Casu, F. Rocco, G. Tancini and E. Scardino, "Paradoxical Stimulation of Prolactin Secretion by L-Dopa in Metastatico Prostate Cancer and Its Possible Role in Prostate-Cancer-Related Hyperprolactinemia," European Urology, Vol. 37, No. 5, 2000, pp. 569-572. doi:10.1159/000020194

[25] A. Negro-Vilar, W. A. Saad and S. M. McCann, "Evidence for a Role of Prolactin in Prostate and Seminal Vesicle Growth in Immature Male Rats," Endocrinology, Vol. 100, No. 3, 1977, pp. 729-737. doi:10.1210/endo-100-3-729

[26] P. W. Harvey, D. J. Everett and C. J. Springall, “Adverse Effects of Prolactin in Rodents and Humans: Breast and Prostate Cancer," Journal of Psichopharmacology, Vol. 22, No. 2, 2008, pp. 20-27. doi: $10.1177 / 0269881107082624$

[27] Y. de Launoit, R. Kiss, V. Jossa, M. Coibion, R. J. Paridaens, E. De Backer, A. J. Danguy and J. L. Pasteels, "Influences of Dihydrotestosterone, Testosterone, Estradiol, Progesterne, or Prolactin on the Cell Kinetics of Human Hyperprolastic Prostatic Tissue in Organ Culture," Prostate, Vol. 13, No. 2, 1988, pp. 143-153. doi:10.1002/pros.2990130206

[28] L. Romero, C. Muñoz, A. López and J. Vilches, "Relation of Prolactin with Nodular Hyperplasia and Carcinoma of the Prostate," Actas Urologicas Españolas, Vol. 15, No. 6, 1991, pp. 503-509.

[29] D. Giuffrida, A. Perdichizzi, M. C. Giuffrida, S. La Vignera, R. D'Agata, E. Vicari and A. E. Calogero, "Does Prolactin Induce Apoptosis? Evidences in a Prostate Cancer in Vitro Model," Journal of Endocrinological Investigation, Vol. 33, No. 5, 2010, pp. 313-317.

[30] T. J. Ahonen, P. L. Härkönen, J. Laine, H. Rui, P. M. Martikainen and M. T. Nevalainen, "Prolactin Is a Sur- 
vival Factor for Androgen-Deprived Rat Dorsal and Préstate Epithelium in Organ Culture," Endocrinology, Vol. 140, No. 11, 1999, pp. 5412-5421.

doi:10.1210/en.140.11.5412

[31] K. Dillner, J. Kindblom, A. Flores-Morales, R. Shao, J. Törnell, G. Norstedt and H. Wennbo, "Gene Expression Analysis of Prostate Hyperplasia in Mice Overexpressing the Prolactin Gene Specifically in the Prostate," Endocrinology, Vol. 144, No. 11, 2003, pp. 4955-4966. doi:10.1210/en.2003-0415

[32] A. Colao, G. Vitale, A. Di Sarno, S. Spiezia, E. Guerra, A. Ciccarelli and A. Lombardi, "Prolactin and Prostate Hypertrophy: A Pilot Observational, Prospective, CaseControl Study in Men with Prolactinoma," Journal of Clinical Endocrinology and Metabolism, Vol. 89, No. 6, 2004, pp. 2770-2775. doi:10.1210/jc.2003-032055

[33] S. J. McPherson, H. Wang, M. E. Jones, J. Pedersen, T. P. Lismaa, N. Wreford, E. R. Simpson and G. P. Risbridger, "Elevated Androgens and Prolactin in Aromatesa-Defiicient Mice Cause Enlargement, But Not Malignancy, of the Prostate Gland," Endocrinology, Vol. 142, No. 6, 2001, pp. 2458-2467. doi:10.1210/en.142.6.2458

[34] A. Ruffion, K. A. Al-Sakkaf, B. L. Brown, C. L. Eaton, F. C. Hamdy and P. R. Dobson, "The Survival Effect of Prolactin on PC3 Prostate Cancer Cells," European Urology, Vol. 43, No. 3, 2003, pp. 301-308. doi:10.1016/S0302-2838(03)00038-1

[35] N. N. Tam, C. Y. Szeto, J. M. Freudenberg, A. N. Fullenkamp, M. Medvedovic and S. M. Ho, "Research Resource: Estrogen-Driven Prolactin-Mediated Gene-Expression Networks in Hormone-Induced Prostatic Intraepithelial Neoplasia," Molecular Endocrinology, Vol. 24, No. 11, 2010, pp. 2207-2217. doi:10.1210/me.2010-0179

[36] Z. Z. Hu, "Study of the Interrelationship of Prolactin Secretion, Thyroid and Ovarian Function," Zhonghua Fu Chan Ke Za Zhi, Vol. 19, No. 4, 1984, pp. 210-214.

[37] A. Ouhtit, G. Morel G and P. A. Kelly, "Visualization of Gene Expression of Short and Long Forms of Prolactin Receptor in Rat Reproductive Tissues," Biology of Reproduction, Vol. 49, No. 3, 1993, pp. 528-536. doi:10.1095/biolreprod49.3.528

[38] J. Rillema, "Prolactin Actions. Encyclopedia of Reproduction," Academic Press, New York, 1999.

[39] M. E. Freeman, B. Kanyicska, A. Lerant and G. Nagy, "Prolactin: Structure, Function, and Regulation of Secretion," Physiological Review, Vol. 80, No. 4, 2000, pp. 1523-1631.

[40] J. Harris, P. M. Stanford, S. R. Oakes and C. J. Ormandy, "Prolactin and the Prolactin Receptor: New Targets of an Old Hormone," Annals of Medicine, Vol. 36, No. 6, 2004, pp. 414-425. doi:10.1080/07853890410033892

[41] P. A. Kelly, N. Binart, M. Freemark, B. Lucas, V. Goffin and B. Bouchard, "Prolactin Receptor Signal Transduction Pathways and Actions Determined in Prolactin Receptor Knockout Mice," Biochemical Society Transactions, Vol. 29, No. 2, 2001, pp. 48-52. doi:10.1042/BST0290048

[42] I. Leav, F. B. Merk, K. F. Lee, M. Loda, M. Mandoki, J. E. McNeal and S. Ho, "Prolactin Receptor Expression in the Developing Human Prostate and in Hyperplastic, Dysplastic, and Neoplastic Lesions," American Journal of Pathology, Vol. 154, No. 3, 1999, pp. 863-870. doi:10.1016/S0002-9440(10)65333-3

[43] B. Lewis, "Traducción de Señales," Oxford University Press, Oxford, 2001.

[44] G. Pearson, J. M. English, M. A. White and M. H. Cobb, "ERK5 and ERK2 Cooperate to Regulate NF-kappaB and Cell Transformation," Journal of Biological Chemistry, Vol. 276, No. 11, 2001, pp. 7927-7931. doi:10.1074/jbc.M009764200

[45] G. Pearson, F. Robinson, G. T. Beers, B. E. Xu, M. Karandikar, K. Berman and M. H. Cobb, "Mitogen-Activated Protein (MAP) Kinase Pathways: Regulation and Physiological Functions," Endocrine Reviews, Vol. 22, No. 2, 2001b, pp. 153-183. doi:10.1210/er.22.2.153

[46] R. Lefloch, J. Pouyssegur and P. Lenormand, "Single and Combined Silencing of ERK1 and ERK2 Reveals Their Positive Contribution to Growth Signaling Depending on Their Expression Levels," Molecular Cell Biology, Vol. 28, No. 1, 2008, pp. 511-527. doi:10.1128/MCB.00800-07

[47] P. D. Maroni, S. Koul, R. B. Meacham and H. K. Koul, "Mitogen Activated Protein Kinase Signal Transduction Pathways in the Prostate," Cell Communication and Signaling, Vol. 2, No. 1, 2004, pp. 114-123. doi:10.1186/1478-811X-2-5

[48] M. A. Dominguez-Caceres, J. M. Garcia-Martinez, A. Calcabrini, L. Gonzalez, P. G. Porque, J. Leon and J. Martin-Perez, "Prolactin Induces c-Myc Expression and Cell Survival through Activation of Src/Akt Pathway in Lymphoid Cells," Oncogene, Vol. 23, No. 44, 2004, pp. 7378-7390. doi:10.1038/sj.onc.1208002

[49] J. Aguilera, "Comunicación Intra e Intercellular," In: M. E. Hernández and A. Ortega, Eds., Fisiología Celular y Molecular: Principios y Conceptos, Universidad Veracruzana, Veracruz, 2004, pp. 97-112.

[50] K. L. Schwertfeger, S. Hunter, L. E. Heasley, V. Levresse, R. P. Leon, J. DeGregori and S. M. Anderson, "Prolactin Stimulates Activation of c-jun N-Terminal Kinase (JNK)," Molecular Endocrinology, Vol. 14, No. 10, 2000, pp. 1592-1602. doi:10.1210/me.14.10.1592

[51] A. Rufion, E. Fontaine and F. Staerman, "Hormonal Therapy in Metastatic Cancer," Progress in Urology, Vol. 13, No. 2, 2003, pp. 334-341.

[52] L. Tangbanluekal and C. L. Robinette, "Prolactin Mediates Estradiol-Induced Inflammation in the Lateral Prostate of Wistar Rats," Endocrinology, Vol. 132, No. 6, 1993, pp. 2407-2416. doi:10.1210/en.132.6.2407

[53] K. Berinder, O. Akre, F, Granath and A. L. Hulting, "Cancer Risk in Hyperprolactinemia Patines: A Population-Based Cohort Study," European Journal of Endocrinology, Vol. 165, No. 2, 2011, pp. 209-215. doi:10.1530/EJE-11-0076

[54] J. F. Sissom, M. L. Eigenbrodt and J. C. Porter, "AntiGrowth Action on Mause Mammary and Prostate Glands of Monoclonal Antibody to Prolactin Receptor," American Journal of Pathology, Vol. 133, No. 3, 1988, pp. 
589-595.

[55] M. Ben-David, T. Kadar and A. V. Schally, "Micromethod for the Determination of Free and Total Prolactin Receptors: Measurement of Receptor Levels in Normal and Malignant Mammary and Prostate Tissues," Proceedings of the National Academy of Sciences, Vol. 83, No. 21, 1986, pp. 8375-8379.

[56] J. R. Dave and R. J. Witorsch, "Prolactin Increases Lipid Fluidity and Prolactin Binding of Rat Prostatic Membranes," American Journal of Physiology, Vol. 248, No. 6, 1985, pp. E687-E693.

[57] P. Mathey, "Efecto de la Hyperprolactinemia Sobre los Niveles de Expresión del RNA Mensajero Para el Receptor a Prolactina y vías de Señalización en la Próstata," Ph.D. Thesis, Universidad Veracruzana, México, 2011.

[58] W. Lou, Z. Ni, K. Dyer, D. J. Tweardy and A. C. Gao, "Interleukin-6 Induces Prostate Cancer Cell Growth Accompanied by Activation of State Signaling Pathway," Prostate, Vol. 42, No. 3, 2000, pp. 239-242. doi:10.1002/(SICI)1097-0045(20000215)42:3<239::AIDPROS10>3.0.CO;2-G

[59] M. T. Spiotto and T. D. Chung, "STAT3 Mediates IL-6-Induced Growth Inhibitionin the Human Prostate Cancer Cell Line LNCaP," Prostate, Vol. 42, No. 2, 2000, pp. 88-98.

doi:10.1002/(SICI)1097-0045(20000201)42:2<88::AID-P ROS2>3.0.CO;2-P

[60] L. Tam, L. M. McGlynn, P. Traynor, R. Mukherjee, J. M. S. Bartlett and J. Edwards, "Expression Levels of the JAK/STAT Pathway in the Transition from HormoneSensitive to Hormone-Refractory Prostate Cancer," British Journal of Cancer, Vol. 97, No. 7, 2007, pp. 378383. doi:10.1038/sj.bjc. 6603871

[61] J. Abdulghani, L. Gu, A. Dagvadorj, J. Lutz, B. Leiby, G. Bonuccelli, M. P. Lisanti, T. Zellweger, K. Alanen, T. Mirtti, T. Visakorpi, L. Bubendorf and M. T. Nevalainen, "Stat3 Promotes Metastatic Progression of Prostate Cancer," American Journal of Pathology, Vol. 172, No. 6, 2008, pp. 1717-1728. doi:10.2353/ajpath.2008.071054

[62] X. Liu, Z. He, C. H. Li, G. Huang, C. Ding and H. Liu, "Correlation Analysis of JAK-STAT Pathway Components on Prognosis of Patients with Prostate Cancer," $\mathrm{Pa}$ thology Oncology Research, Vol. 18, No. 1, 2012, pp. 1723. doi:10.1007/s12253-011-9410-y

[63] A. Dagvadorj, S. H. Tan, Z. Liao, J. Xie, M. Nurmi, K. Alanen, H. Rui, T. Mirtti and M. T. Nevalainen, "NTerminal Truncation of Stat5a/b Circumvents PIAS3Mediated Transcriptional Inhibition of Stat5 in Prostate Cancer Cells," International Journal of Biochemistry and Cell Biology, Vol. 42, No. 12, 2010, pp. 2037-2046. doi:10.1016/j.biocel.2010.09.008

[64] J. Lin, R. M. Adam, E. Santiestevan and M. R. Freeman, "The Phosphatidylinositol 30-Kinase Pathway Is a Dominant Growth Factor-Activated Cell Survival Pathway in LNCaP Human Prostate Carcinoma Cells," Cancer Research, Vol. 59, No. 12, 1999, pp. 2891-2897.

[65] M. E. Cox, P. D. Deeble, S. Lakhani and S. J. Parsons, "Adquisition of Neuroendocrine Characteristics by Prostate Tumor Cells Is Reversible: Implicatios for Prostate
Cancer Progression," Cancer Research, Vol. 59, No. 15, 1999, pp. 3821-3830.

[66] M. E. Hernandez, A. Soto-Cid, F. Rojas, L. I. Pascual, G. E. Aranda-Abreu, R. Toledo, L. I. Garcia, A. QuintanarStephano and J. Manzo, "Prostate Response to Prolactin in Sexually Active Male Rats," Reproductive Biology and Endocrinology, Vol. 14, No. 4, 2006, pp. 28-38. doi:10.1186/1477-7827-4-28

[67] K. E. Lane, I. Leav, J. Ziar, R. S. Bridges, W. M. Rand and S. M. Ho, "Suppression of Testosterone and Estradiol-17beta-Induced Dysplasia in the Dorsolateral Prostate of Noble Rats by Bromocriptine," Carcinogenesis, Vol. 18, No. 8, 1997, pp. 1505-1510. doi:10.1093/carcin/18.8.1505

[68] M. J. Linja, K. P. Porkka, Z. Kang, K. J. Savinainen, O. A. Janne, T. L. J. Tammela, R. L. Vessella, J. J. Palvimo and T. Visakorpi, "Expression of Androgen Receptor Coregulators in Prostate Cancer," Clinical Cancer Research, Vol. 10, No. 3, 2004, pp. 1032-1040. doi:10.1158/1078-0432.CCR-0990-3

[69] J. G. Ma, W. P. Li and Y. Q. Jiang, "Androgen Receptor Mutation and Progression of Prostate Cancer," Zhonghua Nan Ke Xue, Vol. 17, No. 7, 2011, pp. 649-654.

[70] S. Sluczanowska-Glabowska, M. Laszczynska, M. Wylot, W. Glabowski, M. Piasecka and D. Gacarzewicz, "Morphological and Immunohistological Compare of Three Rat Préstate Lobes (Lateral, Dorsal and Ventral) in Experimental Hyperprolactinemia," Folia Histochemica et Cytobiologica, Vol. 48, No. 3, 2010, pp. 447-454. doi:10.2478/v10042-010-0074-3

[71] S. K. Hong, J. H. Kim, M. F. Lin and P. R. K. JI, "The Raf/MEK/Extracellular Signal-Regulated Kinase 1/2 Pathway Can Mediate Growth Inhibitory and Differentiation Signaling via Androgen Receptor Downregulation in Prostate Cancer Cells," Experimental Cell Research, Vol. 317, No. 18, 2011, pp. 2671-2682. doi:10.1016/j.yexcr.2011.08.008

[72] S. H. Tan, A. Dagvadorj, F. Shen, L. Gu, Z. Liao, J. Abdulghani, Y. Zhang, E. P. Gelmann, T. Zellweger, Z, Culig, T. Visakorpi, L. Bubendorf, R. A. Kirken, J. Karras and M. T. Nevalainen, "Transcription Factor Stat5 Synergizes with Androgen Receptor in Prostate Cancer Cells," Cancer Research, Vol. 68, No. 1, 2008, pp. 236-248. doi:10.1158/0008-5472.CAN-07-2972

[73] W. C. Guftason and W. A. Weiss, "Myc Proteins as Therapeutic Targets," Oncogene, Vol. 29, No. 9, 2010, pp. 1249-1259. doi:10.1038/onc.2009.512

[74] C. M. Koh, C. J. Bieberich, C. V. Dang, W. G. Nellson, S. Yegnasubramanian and A. M. DeMarzo, "Myc and Prostate Cancer," Genes and Cancer, 2010, Vol. 1, No. 6, pp. 617-628. doi:10.1177/1947601910379132

[75] D. S. Rickman, T. D. Soonfg, B. Moss, J. M. Mosquera, J. Dlabal, S. Terry, T. Y. MacDonald, J. Tripodi, K. Bunting, V. Najfeld, F. Demichelis, A. M. Melnick, O. Elemento and M. A. Rubin, "Oncogene-Mediated Alterations in Chromatin Conformation," Proceedings of the National Academy of Sciences, 2012, Vol. 109, No. 23, pp. 9083-9088. doi:10.1073/pnas.1112570109

[76] J. Wang, T. Kobayashi, N. Floch, C.W. Kinkade, A. Ay- 
tes, D. Dankort, C. Lefevbre, A. Mitrofanova, R. D. Cardiff, M. McMahon, A. Califano, M. M. Shen and C. Anatte-Shen, "B-Raf Activation Cooperates with PTEN Loss to Drive c-myc Expression in Advanced Prostate Cancer," Cancer Research, 2012, Vol. 72, No. 18, pp. $1-12$.

[77] M. D. Amatangelo, S. Goodyear, D. Varma and M. E. Stearns, "c-Myc Expression and MEK1-Induced Erk2 Nuclear Localization Are Required for TGF-Beta Induced Epithelial-Mesenchymal Transition and Invasion in Prostate Cancer," Carcinogenesis, 2012, Vol. 1, No. 1, pp. 1965-1975. doi:10.1093/carcin/bgs227

[78] S. Yamamura, S. Saini, S, Majid, H. Hirata, K. Ueno, G. deng and R. Dahiya, "MicroRNA-34a Modulates c-myc Transcriptional Complex to Suppress Malignancy in $\mathrm{Hu}-$ man Prostate Cancer Cells," Plos ONE, Vol. 7, No. 1, pp. 1-12.

[79] B. Benassi, R. Flavin, L. Marchionni, S. Zanata, Y. Pan, D. Chowdhury, M. Marani, S. Strano, P. Muti, G. Blandino and M. Loda, "MYC Is Activated by USP2aMediated Modulation of microRNAs in Prostate Cancer," Cancer Discovery, 2012, Vol. 2, No. 3, pp. 236-247. doi:10.1158/2159-8290.CD-11-0219

[80] N. Nadiminty, R. Tummala, W. Lou, y. Zhu, J. Zhang, X Chen, W. R. eVere-White, H. J. Kung, C. P. Evans and A. C. Gao, "MicroRNA let-7c Suppresses Androgen Receptor Expression and Activity via Regulation of Myc Expression in Prostate Cancer Cells," Jornal Biology Chemistry, 2012, Vol. 287, No. 2, pp. 1527-1537. doi:10.1074/jbc.M111.278705 